\title{
Cuts spark strike at Australian universities
}

Sydney. The battle over higher education funding in Australia spilled into the streets last week when academic staff, general staff and students of all 36 public universities staged an unprecedented national strike. About 30,000 protesters took part in demonstrations, and universities were closed by picket lines, prompted by plans for cutting public expenditure being drawn up by the newly-elected conservative Coalition government.

The protest stemmed from the threat of cuts of up to 12 per cent in operating grants, totalling around $\mathbf{A} \$ \mathbf{5 5 0}$ million (US\$433 million) per annum, hinted at by the new federal Minister for Education, Senator Amanda Vanstone, in a meeting with vice-chancellors last month (see Nature 381, 265; 1996).

Vanstone has denied that any decisions have been made over the level of cuts. But she is holding firm to an instruction from John Howard, the Prime Minister, that ministers should not reveal where cuts totalling $\mathbf{A} \$ 8$ billion over the next two years are to be applied until the government's first budget, due in August.

After attacking the vice-chancellors in parliament for taking "an irresponsible attitude" by avoiding their responsibility to contribute to the task of meeting the government's goal, as well as for "using the meeting as an opportunity to obtain media coverage", she appealed to them to tell her how they would prefer to handle the reduced funding.

But the vice-chancellors have resisted doing what they consider to be the government's work, and have asked Howard for an urgent meeting. Fay Gale, vice-chancellor of the University of Western Australia and president of the Australian Vice-Chancellors' Committee, said in a letter to Howard that the cuts would have a "devastating effect" on universities.

Meanwhile a consortium of science organizations - backed, intriguingly, by the conservative Farmers' Federation - held a joint press conference protesting against rumoured cuts to research funding. Joe Baker, president of the Federation of Australian Scientific and Technological Organisations, who convened the meeting, described cuts to the funding of research and teaching institutions as "like slashing the wrists of the economy".

A leaked government document has suggested that one way of reducing funding of the Commonwealth Scientific and Industrial Research Organization (CSIRO), would be through applying an 'efficiency dividend' of three per cent of its budget, amounting to A\$12 million. CSIRO has already been subject to a 'dividend' of $\mathbf{1 . 5}$ per cent only to its administration, intended to reflect better management and use of technology. Now the threat is to apply an increased dividend across the board, including to research programmes.

Speaking in a television interview, Malcolm McIntosh, the chief executive of CSIRO, said he hoped that the government would not only maintain CSIRO's base funding, but even increase it. "As soon as you do it [a three per cent cut] across the rest of the spectrum, it cuts the science we can do and that is, we believe, contrary to the commitment the government made in its election campaign," he said.

At the same time the business community - ironically the backbone of the conservative government - is itself objecting to reports that a popular scheme of encouraging industrial research and development through 150 per cent tax concessions, introduced by the previous Labor government, is to be watered down. A delegation of research managers emerged from a meeting with John Moore, the cabinet-level Minister for Industry, Science and Tourism, expressing concern that he was not prepared to comment on such reports.

Peter Pockley

\section{Agricultural institutes 'to favour developing countries'}

London. The Consultative Group on International Agricultural Research (CGIAR), an international network of agricultural research organizations, backed by the United Nations, last week promised to reorient its research programmes to improve its ability to meet the needs of developing countries.

The move reflects long-standing accusations made against the organization for having put the interests of the industrialized world before those of Third World farmers.

CGIAR was set up in 1971 to conduct research into the cultivation of basic food crops. It is sponsored by the World Bank, the UN Food and Agriculture Organisation and the UN Development Programme. Although 16 of CGLAR's member states are from developing countries, its board is dominated by representatives from its 21 industrialized country members. Indeed, four countries - Australia, Canada, the United Kingdom and the United States - hold half of all key positions in the group.

Environmentalist groups have frequently claimed that this imbalance biases CGIAR's actions towards the interests of industrialized countries. They have also accused it of having promoted unsustainable agriculture through, for example, its focus on highyielding crop varieties and chemical fertilizers. Critics argue that while such an approach has boosted crop yields, it has also

\section{IMAGE UNAVAILABLE FOR COPYRIGHT REASONS}

Weighing up: CGIAR has decided to increase its focus on the needs of developing countries.

reduced the genetic diversity of crop plants and polluted water supplies.

In what seems to be a move aimed at offsetting such criticism, a meeting of the CGIAR in Jakarta, Indonesia last week endorsed a proposal from its Technical Advisory Committee that all research at its 16 centres should be focused on the needs of developing countries, where most of the centres themselves are located.

Ismail Serageldin, the chairman of
CGIAR, says that its research programmes up to the year 2000 "will be skewed in favour of the poor". He adds that the research bodies "would fail in our noble mission if

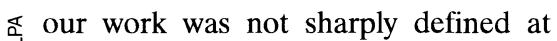
fighting the misery and hunger of small ( farmers and landless poor".

Some critics remain unconvinced that 产 this shift in strategy will be translated into action. "We are still very sceptical," says Henk Hobblelink from Genetic Resource Action International, a nongovernmental organization based in Barcelona, Spain.

Furthermore, non-governmental organizations from developing countries remain concerned that the CGIAR's control over germplasm means industrialized countries gain most of the benefits from increased yields and new varieties. "CGIAR has to get its politics of benefit-sharing correct first," says Sunita Narian, deputy director of the Centre for Science and Environment, New Delhi.

But the organization insists that the interests of the developing world have always been its priority. Last week's decision is only intended to give its research a sharper focus, says Heinrich von Loesch, a spokesman for the CGIAR secretariat in Washington.

Anju Sharma 